\title{
Evidence for Polymorphism of Merkel Cells in the Adult Human Oral Mucosa*
}

\author{
Tamiko Tachibana, Takuya Kamegai, Naoki Takahashi and Tokio NaWa \\ Department of Oral Anatomy, Iwate Medical University School of Dentistry, Morioka, Japan
}

Received January 21, 1998

Summary. We recently reported that Merkel cells in the normal palatine mucosa of adult rodents are highly polymorphic. In order to ascertain whether or not this polymorphism is also evident in the human oral mucosa, palatine mucosae from cadavers without oral diseases and perilesional palatine mucosae of patients with pleomorphic adenoma were examined by immunohistochemistry using an antibody against cytokeratin 20 .

Findings showed that Merkel cells in the human normal palatine mucosa were polymorphic, and a number of irregular-shaped Merkel cells (dendritic Merkel cells) with apparent cytoplasmic projections were present among typical oval to round Merkel cells. The mucosa usually contained a small number of oval to round Merkel cells residing in ectopic places such as prickle and granular cell layers. On the other hand, the slightly inflamed perilesional palatine mucosa contained an increased incidence of dendritic Merkel cells. Ectopic Merkel cells were rare in the perilesional palatine mucosa.

Characteristics of dendritic Merkel cells were examined using specimens from perilesional palatine mucosae by means of immunohistochemistry and electron microscopy. It was shown that every dendritic Merkel cell and most roundish Merkel cells in the perilesional mucosa lacked innervation. Electron microscopy suggested that dendritic Merkel cells release secretory granules from the tip of the cytoplasmic process and the basal cytoplasm towards the lamina propria mucosae, in a manner resembling the case of similar cells in rodents.

Merkel cells (MCs) comprise a characteristically granulated cell type in the skin and oral mucosa, and are known to be innervated with $\mathrm{A} \alpha$ sensory nerve fibers. The true function of these cells is still enigmatic, though some possibilities such as mechanical transduction and trophic and/or inductive involvement in the growth of peripheral nerves and epithelial cells have been argued (for reviews see: HARTSCHUH et al., 1986; TACHIBANA, 1995; OGAWA, 1996).

Since their discovery by MERKEL (1875), it has long been accepted that mammalian MCs generally possess oval to spherical cell bodies. However, recent immunohistochemical studies using antibodies against cytokeratin markers specific for MCs, such as cytokeratins $8,18,19$ and 20 , have shown that the normally developing cutaneous anlagen frequently contain so-called dendritic MCs (DMCs) characterized by an irregular-shaped cell body and the protrusion of cytoplasmic processes (MoLL, R. et al., 1984, Moll, I. et al., 1986; NARISAWA et al., 1993a, b; KIM and HOLBROOK, 1995; VIELKIND et al., 1995). Similar DMCs have also been identified in terminal hair follicles of normal adult skin (NARISAWA et al., 1994a) and in hair follicles and follicle germs in peri- and intralesional skin samples from patients with desmoplastic trichoepithelioma, trichoblastoma, and nevus sebaceus (HARTSCHUH and SCHULZ, 1995; SCHULZ and HARTSCHUH, 1995, 1997). These DMCs have been presumed to have a stimulatory influence on the growth and proliferation of peripheral nerve fibers and/or epithelial cells (MoLL, R. et al., 1984; MoLL, I. et al., 1986; NARISAWA et al., 1993a, b, 1994a, b; KIM and HolBROOK, 1995; HARTSCHUH and SCHULZ, 1995; SCHULZ and HARTSCHUH, 1995, 1997).

Recently, we found that MCs in the normal palate of adult rodents are highly polymorphic with an abundance of DMCs (TACHIBANA et al., 1997). As the polymorphism of MCs in mature tissues may imply the functional heterogeneity of these cells, it seems

*This study was supported by a grant-in-aid for scientific research (No. 08877283 to T. T.) from the Ministry of Education, Science, Sports, and Culture, Japan. 
important to determine whether or not the phenomenon is species specific. Although our preliminary study indicated the occurrence of a small number of DMCs in the normal human palatine mucosa, no systematic studies have been available concerning the polymorphism of human oral Merkel cells. Therefore, we decided to examine the morphology of MCs in the adult human oral mucosae from cadavers, employing immunohistochemistry using monoclonal antibody against cytokeratin 20 , presently the most reliable marker for MCs (MoLL, R. et al., 1992).

The polymorphism of MCs being subsepuently ascertained, we next advanced to an investigation of the innervation and ultrastructure of DMCs using biopsies obtained from the periphery of surgically excised pleomorphic adenomas. Surprisingly, the slightly inflamed perilesional palatine mucosae contained a greater abundance of DMCs than the normal palatine mucosa from cadavers. We therfore compared the incidences of DMCs in normal and perilesional palates, further studying the innervation and ultrastructure of these cells using perilesional palatine mucosae, employing dual-channel confocal laser scanning microscopy after double-labeling immunohistochemistry with a monoclonal antibody against cytokeratin 20 and a polyclonal antibody against protein gene product 9.5 (PGP 9.5), the latter being a marker of peripheral nerve fibers. In addition, immunoreactivities of DMCs toward antibodies against neurofilaments, vimentin, and actin were examined to check whether or not DMCs express these proteins in a manner similar to carcinomatous MCs.

\section{MATERIALS AND METHODS}

Normal palatine mucosae free of any apparent oral disease were collected from male $(n=12)$ and female $(n=10)$ cadavers of individuals ranging between 44 and 92 years of age (average: 75 years), who had voluntarily donated their bodies for anatomical practice by students of Iwate Medical University. These cadavers had been perfused with a fixative containing $14 \%$ formalin, $36 \%$ ethanol, and $2 \%$ glycerin after death and then immersed in a warmed similar fixative for $12 \mathrm{~h}$. Every cadaver had been stored in a refrigerator for 6 months or more prior to collection of the mucosal tissue. Small blocks of mucosae of about $10 \times 10 \mathrm{~mm}$ were excised from the middle portion of the hard palate and embedded in paraffin after an additional fixation in $4 \%$ paraformaldehyde for one week.

Small pieces of palatine mucosae of about $2 \times 5 \mathrm{~mm}$ were obtained from the perilesional margin of surgically excised pleomorphic adenomas $(n=5)$. Subjects were all female, ranging between 51 and 74 years of age (average: 59 years). For reference, small blocks of biopsies of gingival mucosae affected by severe gingivitis and the perilesional palatine mucosa of a patient with leukoplakia were also obtained. The specimens had been immersed in $10 \%$ neutralized formalin for over one week prior to use. Specimens were divided into two blocks when possible, and then processed for paraffin embedding and electron microscopy or cryostat sectioning. For paraffin embedding and cryostat sectioning, the specimens were reimmersed in a fixative of $4 \%$ paraformaldehyde plus $0.2 \%$ picric acid dissolved in phosphate buffer ( $\mathrm{pH}$ 7.4) for one week at room temperature. For electron microscopy, specimens were cut into small pieces and fixed in $2.5 \%$ glutaraldehyde dissolved in cacodylate buffer ( $\mathrm{pH}$ 7.4) for $1 \mathrm{~h}$ at room temperature followed by postfixation in $1 \% \mathrm{OsO}_{4}$.

\section{Immunohistochemistry}

Serial paraffin sections of $15-\mu \mathrm{m}$ thickness were cut from specimens of normal and perilesional palatine mucosae and pathologic gingival mucosae. Dewaxed sections were stained by the indirect immunoperoxidase method using a monoclonal antibody against cytokeratin 20 (CK20) (Mab. IT-Ks 20.8; Progen, Heidelberg) as follows: Sections were immersed in 1\% $\mathrm{H}_{2} \mathrm{O}_{2}$ dissolved in methanol for 30 min to block intrinsic peroxidase activity, and then saponified in $0.2 \%$ Triton X-100 dissolved in PBS for 30 min. After being washed in PBS, the sections were trypsinized with 0 . $05-0.2 \%$ trypsin for $30 \mathrm{~min}$ at room temperature for the purpose of antigen unmasking. Sections were next incubated in a 1: 20 dilution of the anti-CK20 at $4^{\circ} \mathrm{C}$ overnight subsequent to preincubation in $0.3 \%$ normal horse serum. Reaction products were developed by use of a commercially supplied avidin-biotin complex $(\mathrm{ABC})$ kit comprising biotinylated antimouse IgG and HRP-conjugated avidin-biotin complex (Vector, Burlingame), and then visualized with diaminobenzidine. Sections were counterstained with hematoxylin and then mounted in Entellan neu (Merck, Darmstadt).

Monoclonal antibodies that recognize 150 and 200$\mathrm{kD}$ neurofilament components (Mab. 13AA; BIOHIT, Helsinki) and a 70-kD component (Mab. M-726; Dakopatts, Glostrup) were applied to $5-\mu \mathrm{m}$ frozen sections of the perilesional palatine mucosa at dilutions of 1: 300 and 1:200, respectively. A monoclonal antiserum against vimentin (Mab. 65E; BIOHIT, Helsinki) and rabbit polyclonal antiserum against actin (Biomedical, Stoughon) were applied to $5-\mu \mathrm{m}$ 


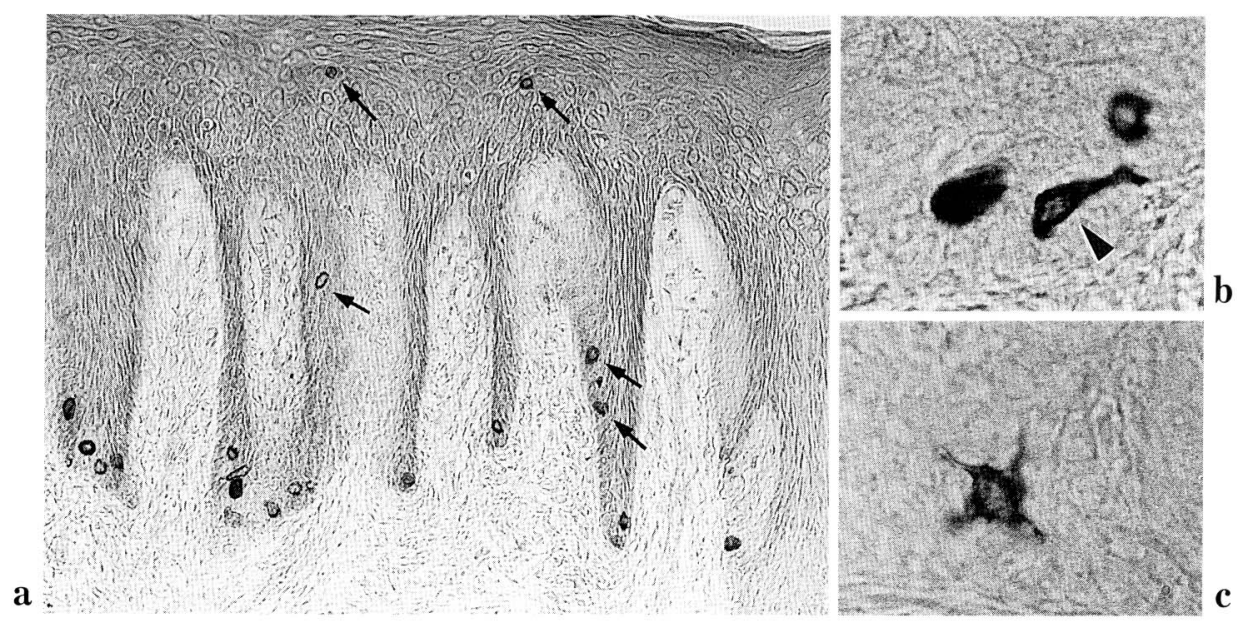

Fig. 1 a-c. Distribution and shapes of CK20-immunoreactive cells (Merkel cells) in normal palatine mucosae from cadavers. Although most Merkel cells are seen in apices of epithelial ridges, some cells are seen in ectopic locations on the epithelium (a, arrows). Dendritic Merkel cells of a droplet shape (b, arrowhead) and that of a polygonal shape $(\mathbf{c})$ can be seen. a: $\times 150, \mathrm{~b}, \mathrm{c}: \times 600$

paraffin sections at dilutions of $1: 300$ and 1:50, respectively. After the sections had been incubated in solutions of these primary antisera at $4^{\circ} \mathrm{C}$ overnight, the reaction product was developed by the $\mathrm{ABC}$ technique using appropriate ABC-kits (Vector, Burlingame) and visualized by the $\mathrm{DAB}$ reaction.

\section{Estimation of the incidence of dendritic Merkel cells (DMCs)}

Sections stained by immunohistochemistry for antiCK20 were observed under a light microscope, and the number of MCs containing a nucleus in their center was counted. MCs were classified into two categories: typical MCs characterized by oval to spherical external figures, and DMCs with irregular shapes. The incidence of DMCs among total MCs was calculated. As some typical MCs were found to be located ectopically, the incidence of ectopic MCs was also estimated. Statistical analyses were made by use of a computerized statistic software, SigmaPlot 4.14 (Jandel Corp.)

\section{Confocal laser scanning microscopy}

Dewaxed and rehydrated $15-\mu \mathrm{m}$ thick paraffin sections of perilesional palatine mucosae from pleomorphic adenoma and leukoplakia were saponificated and trypsinized after the blockage of intrinsic peroxidase activity as mentioned above. The sections were preincubated in an equal part mixture of $0.3 \%$ normal horse serum and $0.3 \%$ normal goat serum for 20 min and then incubated in an equal part mixture of a
1: 10 dilution of monoclonal anti-CK20 and a 1:200 dilution of rabbit antibodies for protein gene product 9.5 (PGP 9.5; UltraClone, Isle of Wight) at $4^{\circ} \mathrm{C}$ overnight. After having been washed in PBS, reaction products were labeled by sequential incubations in a 1:100 dilution of fluorescein-labeled anti-mouse IgG (Vector, Burlingame) and a 1:40 dilution of rhodamine-conjugated anti-rabbit IgG (Kirkegaar \& Perry, Gaithersburg). Stained sections were mounted in glycerin-PBS plus $0.1 \% p$-phenilenediamine and observed by dual-channel confocal laser scanning microscopy.

\section{Electron microscopy}

Small formalin-fixed blocks of perilesional palatine mucosa were re-fixed in $2.5 \%$ glutaraldehyde prepared in cacodylate buffer (pH 7.4). Specimens were postfixed in $1 \% \mathrm{OsO}_{4}$ and then embedded in Epon 812. Ultrathin sections were cut, stained with uranium acetate and lead citrate, and observed with an H-7100 electron microscope.

\section{RESULTS}

\section{Incidence of dendritic Merkel cells (DMCs)}

Of 22 specimens of palatine mucosae collected from cadavers, 12 specimens were omitted because of very weak immunoreaction for anti-CK20, probably due to unsuitable preservation of the tissues. The residual 10 specimens were normal in histological appearance 
Table 1. Incidence of dendritic and ectopic Merkel cells in normal palatine mucosae

\begin{tabular}{cccccc}
\hline $\begin{array}{c}\text { Subject } \\
\text { (Sex) }\end{array}$ & Age & Total MCs & $\begin{array}{c}\text { Incidence of } \\
\text { DMCs (\%) }\end{array}$ & $\begin{array}{c}\text { Polygonal cells } \\
\text { in total DMC (\%) }\end{array}$ & $\begin{array}{c}\text { Incidence of } \\
\text { EMCs (\%) }\end{array}$ \\
\hline $1(\mathrm{~m})$ & 44 & 1202 & 34.0 & 40.3 & 5.0 \\
$2(\mathrm{~m})$ & 71 & 1001 & 16.2 & 9.9 & 5.3 \\
$3(\mathrm{~m})$ & 76 & 634 & 7.0 & 12.9 & 7.0 \\
$4(\mathrm{~m})$ & 82 & 507 & 9.6 & 18.9 & 13.2 \\
$5(\mathrm{~m})$ & 85 & 714 & 19.0 & 7.4 & 3.6 \\
$6(\mathrm{~m})$ & 91 & 428 & 5.4 & 81.5 & 1.6 \\
$7(\mathrm{f})$ & 59 & 961 & 9.5 & 16.8 & 12.2 \\
$8(\mathrm{f})$ & 76 & 698 & 19.0 & 26.8 & 15.8 \\
$9(\mathrm{f})$ & 86 & 563 & 0.5 & 100.0 & 16.2 \\
$10(\mathrm{f})$ & 92 & 772 & 22.9 & 45.4 & $9.0 \pm 5.2$ \\
\hline Mean \pm SD & 76 & & $14.3 \pm 9.9$ & $34.0 \pm 31.7$ & \\
\hline
\end{tabular}

MC: Merkel cell, DMC: dendric Merkel cell, EMC: ectopic Merkel cell.

Table 2. Incidence of dendritic and ectopic Merkel cells in the perilesional palatine mucosa of pleomorphic adenoma*

\begin{tabular}{cccccc}
\hline Subject & Age & Total MCs & $\begin{array}{c}\text { Incidence of } \\
\text { DMCs (\%) }\end{array}$ & $\begin{array}{c}\text { Polygonal cells } \\
\text { in total DMCs (\%) }\end{array}$ & $\begin{array}{c}\text { Incidence of } \\
\text { EMCs (\%) }\end{array}$ \\
\hline 1 & 51 & 255 & 38.5 & 64.2 & 0.3 \\
2 & 53 & 615 & 23.5 & 48.5 & 1.8 \\
3 & 56 & 258 & 44.2 & 54.3 & 0.4 \\
4 & 59 & 1048 & 59.0 & 91.9 & 0.2 \\
5 & 74 & 596 & 37.9 & 36.7 & 5.5 \\
\hline Mean+SD & & & $40.6 \pm 12.8$ & $59.1 \pm 20.9$ & $1.6 \pm 2.3$ \\
\hline
\end{tabular}

* All patients were female

MC: Merkel cell; DMC: dendritic Merkel cell; EMC: ectopic Merkel cell.

Table 3. Incidence of dendritic and ectopic Merkel cells in the perilesional palatine mucosa of leukoplakia and the gingival mucosa affected with gingivitis

\begin{tabular}{lcccccc}
\hline \multicolumn{2}{c}{ Materials } & Total MCs & $\begin{array}{c}\text { Incidence of } \\
\text { DMCs (\%) }\end{array}$ & $\begin{array}{c}\text { Polygonal cells } \\
\text { in total DMCs (\%) }\end{array}$ & $\begin{array}{c}\text { Incidence of } \\
\text { EMCs (\%) }\end{array}$ \\
\hline Origin (Sex) & Age & & 32.2 & 64.6 & 0.1 \\
\hline Leukoplakia (f) & 56 & 810 & 49.9 & 98.0 & 6.6 \\
Gingivitis 1 & (f) & 37 & 619 & 57.1 & 3.1 \\
Gingivitis 2 & (f) & 67 & 413 & 54.6 & 47.3 & 0.0 \\
\hline Gingivitis 3 & (m) & 32 & 343 & 66.0 &
\end{tabular}

MC: Merkel cell, DMC: dendritic Merkel cell, EMC: ectopic Merkel cell. 


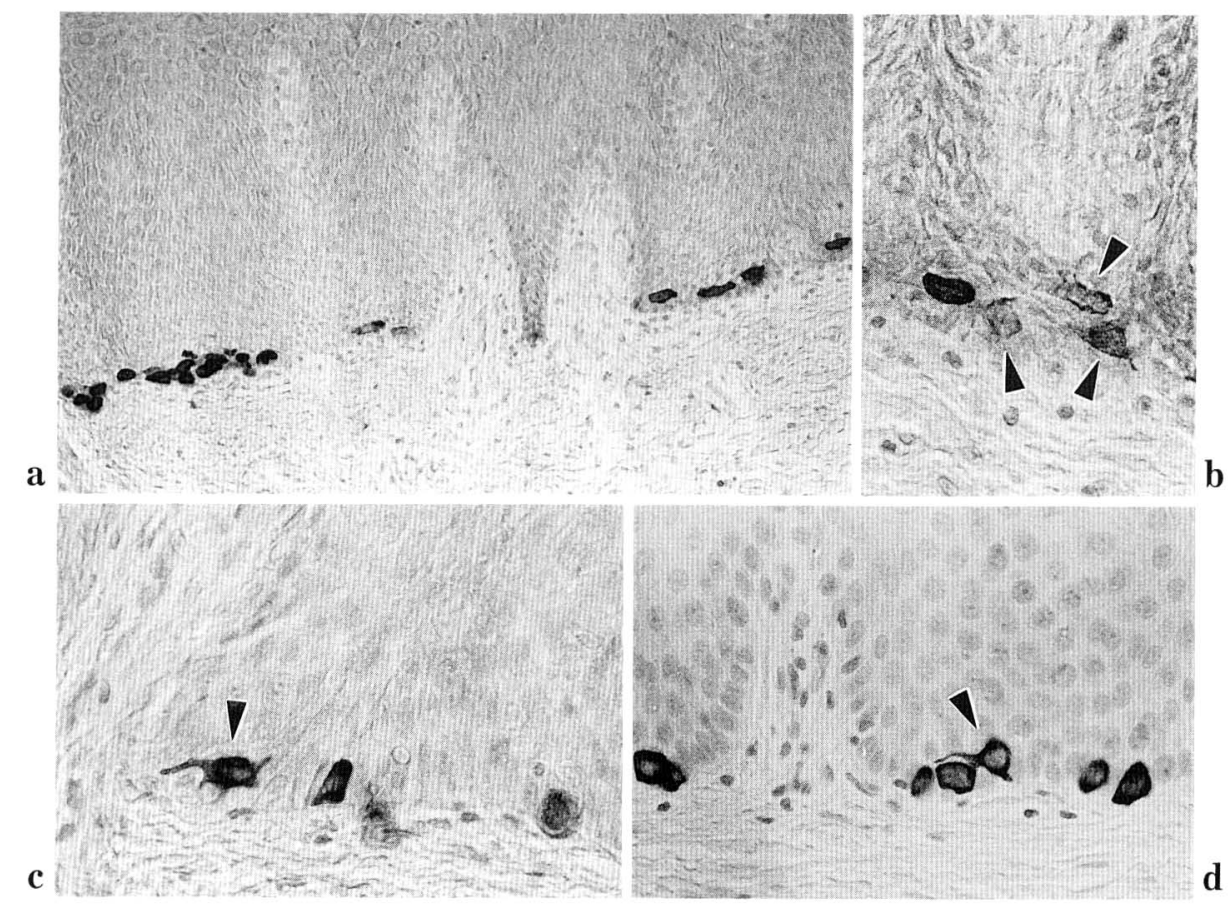

Fig. 2 a-d. CK20-immunoreactive Merkel cells in the perilesional mucosal tissue of palatine pleomorphic adenoma $(\mathbf{a}-\mathbf{c})$ and leukoplakia (d). Merkel cells in a, $\mathbf{c}$ and d were revealed by $0.2 \%$ trypsin digestion, whereas those in $\mathbf{b}$ by $0.01 \%$ trypsin. Note that all Merkel cells locate in the apices of epithelial ridges (a). Also note that dendritic Merkel cells digested with $0.01 \%$ trypsin show weaker immunoreactions (b, arrowheads) than those digested with $0.2 \%$ trypsin (c, d, arrowheads). a: $\times 150$, b-d: $\times 400$

with no inflammatory signs and showed a strong immunoreaction with the anti-CK20 antibody.

Many CK20-immunoreactive MCs were detected in the epithelial layer of the palatine mucosae from cadavers. These cells were predominantly located in the apices of epithelial ridges, but some cells were found in other portions of the epithelium as well as in the connective tissue papillae (Fig. 1a). Although most MCs were oval to spherical in shape, some cells showed irregular external figures. As these irregularshaped MCs usually possessed apparent cytoplasmic processes of various lengths, they were categorized as DMCs. Some DMCs exhibited a droplet or spindle shape with only one to two cytoplasmic processes, whereas others exhibited polygonal shapes with multiple cytoplasmic processes (Fig. 1a-c). These DMCs were usually situated in the apices of epithelial ridges (Fig. 1a-c). The incidence of DMCs among the total MCs encountered in a given serial section varied largely by individuals, ranging from $0.5 \%$ to $34 \%$ (Table 1). The ratio of polygonal-shaped DMCs to total DMCs also differed greatly from individual to individual (Table 1). The incidence of ectopic MCs also varied by individuals from $1.6 \%$ to $16.0 \%$ (Table 1). There was no sign of age- or sex-related trend in the incidence of dendritic or ectopic MCs.

Perilesional palatine mucosae obtained from the periphery of surgically excised pleomorphic adenoma showed an almost normal histological appearance, except that these tissues contained more or less a greater number of lymphocytes than normal palatine mucosae (Fig. 2a-c, cf. Fig. 1a). These perilesional palatine mucosae also contained MCs in the apices of their epithelial ridges, many of them being irregular in shape (Fig. 2a-c). Although some irregularly shaped MCs exhibited vague cytoplasmic processes, we tentatively included them among DMCs. It was calculated that 23 to $60 \%$ of all MCs were of the DMC type, and that more than half of them were polygonal in shape (Table 2). When a comparison was made between the perilesional mucosa of pleomorphic adenoma and the normal palatine mucosa, the mean value of the incidence of DMCs was significantly larger in the former (independent $t$-test; $\mathrm{p}<$ 


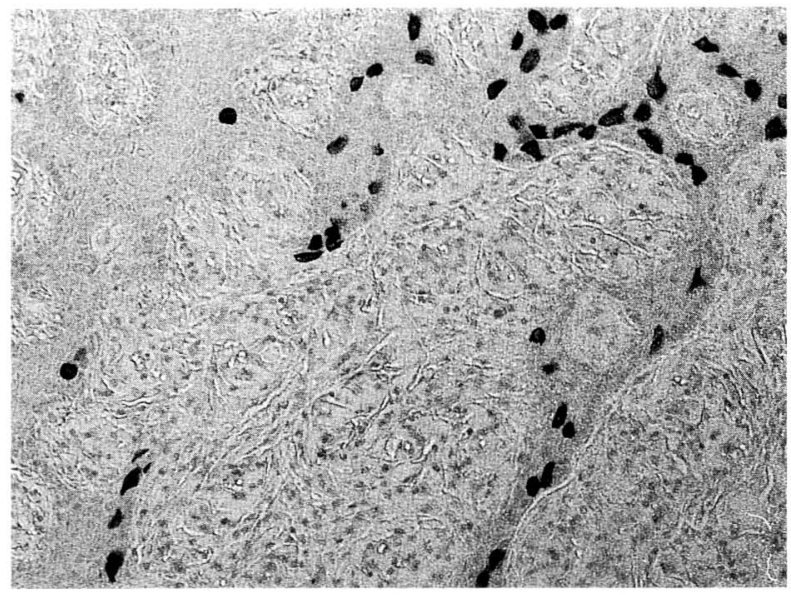

Fig. 3. CK20-immunoreactive Merkel cells in a gingival mucosa affected by gingivitis. Note that the mucosa is highly inflamed and many MCs show irregular shapes. $\times 250$

0.05). By contrast, the mean value of ectopic MCs was significantly small in the perilesional palatine mucosa of pleomorphic adenoma (independent $t$-test; $\mathrm{p}<0.05$, Table 2).

Perilesional palatine mucosa obtained from the periphery of surgically excised leukoplakia showed almost identical patterns in histological appearance and the incidence of DMCs as in the case of pleomorphic adenoma (Fig. 2d, Table 3). On the other hand, gingival mucosae affected by gingivitis showed a severe inflammation and contained a larger percentage of DMCs than perilesional palatine mucosae (Fig. 3, Table 3).

\section{Features of dendritic Merkel cells in the perilesional palatine mucosae}

DMCs in perilesional palatine mucosae usually showed a weaker immunoreactivity for anti-CK20 antibody than typical MCs whenever trypsin for antigen unmasking was used at dilutions below $0.1 \%$ (Fig. 2b). As this fact led to the suspicion that the gene expression for cytofilament proteins might be altered in DMCs, we next examined immunoreactions for neurofilaments, vimentin, and actin. However, no cells in the epithelial layers were stained positively with these antibodies (data not shown).

When perilesional palatine mucosae of pleomorphic adenoma and leukoplakia were examined by dual-channel confocal laser scanning microscopy using anti-CK20 and anti-PGP 9.5, only a small number of nerve fibers reactive for anti-PGP 9.5 were detected in the lamina propria mucosae. Although there were a few oval to round MCs showing close contact with nerve terminal-like structures (Fig. 4a), most similar cells and every DMC exhibited no apposition to such structures (Fig. 4b). We did not encounter any innervated MC in the current electron microscopy for the perilesional palatine mucosa.

DMCs in the perilesional palatine mucosa of both pleomorphic adenoma and leukoplakia contained abundant secretory granules in their cytoplasmic processes and in the basal cytoplasm (Fig. 5a, b). Both a close abutment against the cell membrane and exocytotic image of these granules were sometimes seen at the basal surface of DMCs (Fig. 5b). On the other hand, it was sometimes observed that MCs, not only definite DMCs but also apparently spherical MCs, were in close contact with agranular leukocytes (Fig. 5c). Such a close proximity between MCs and leukocytes was seen in 9 cells among $35 \mathrm{MCs}$ (about $26 \%$ ) encountered in samples of pleomorphic adenoma and in 5 cells among $30 \mathrm{MCs}$ (17\%) encountered in samples of leukoplakia. However, secretory granules in these MCs were not necessarily concentrated in the cytoplasm facing the leukocyte (Fig. 5c).

\section{DISCUSSION}

We recently found that MCs in the normal palatine mucosa of adult rodents are polymorphic and contain abundant dendritic Merkel cells (DMCs) which lack innervation (TACHIBANA et al., 1997). Similarly, human palatine mucosa was also found in the present study to contain DMCs, though the incidence of these cells was relatively low in the normal mucosa. These facts suggest that oral mucosal MCs in vertebrates are generally heterogeneous in morphology and probably in function as well.

The current study showed that the human normal palatine mucosa usually contains not only DMCs but also ectopically residing MCs. Previous authors have reported that the normal human oral mucosa usually contains a number of non-innervated MCs (RAMIERI et al, 1992; Hillinges et al., 1996). We previously found that MCs in the denervated labial mucosa of the rabbit migrated from their original basal loci to superficial layers of the epithelium (TACHIBANA et al., 1982). In addition, we have recently found that the rodent normal palatine mucosa contains many $\mathrm{MCs}$ having intermediate features between typically innervated roundish MCs and non-innervated DMCs (TACHIBANA et al., 1997). Therefore, it seems probable that, while some of denervated MCs in the normal human oral mucosa migrate out from the epithelium, 

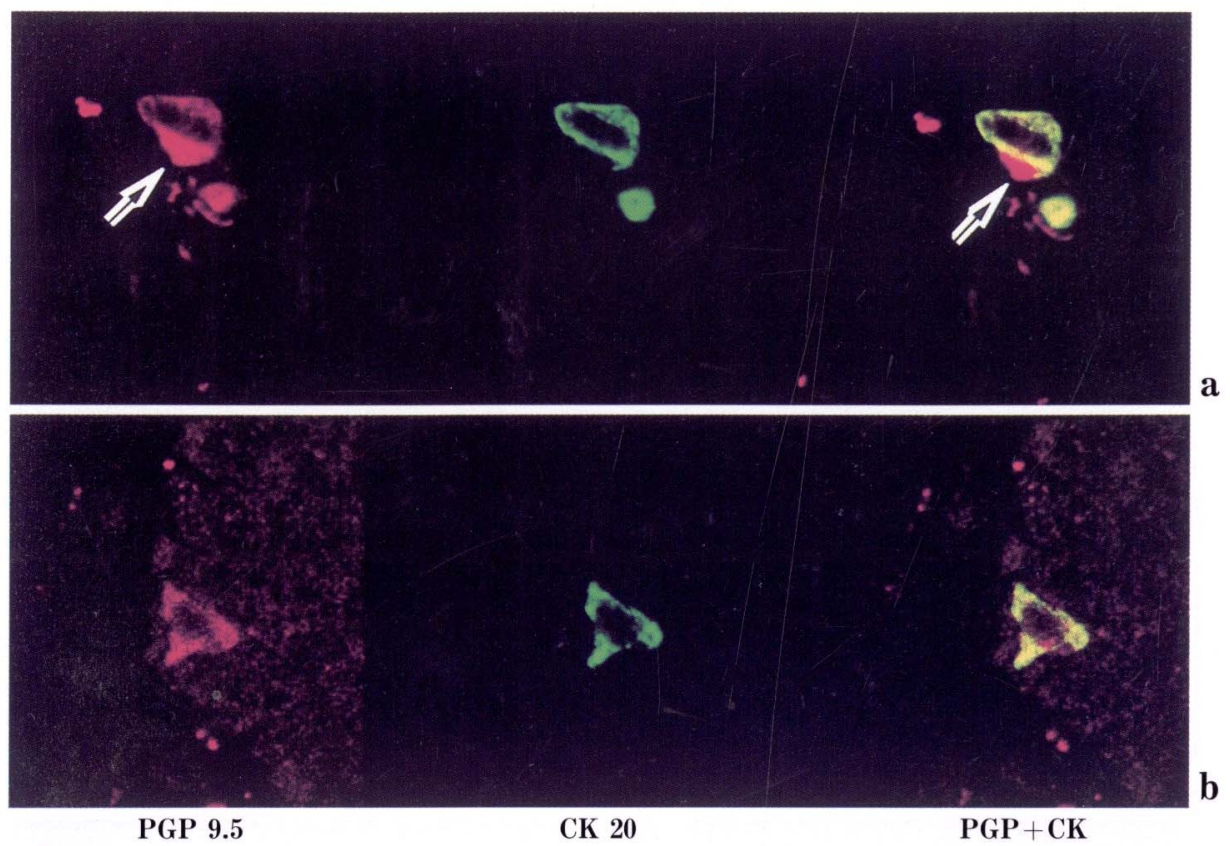

Fig. $4 \mathbf{a}$ and $\mathbf{b}$. Confocal laser scanning micrographs of Merkel cells in the same section of perilesional palatine mucosa of pleomorphic adenoma. The section was doubly stained by an immunofluorescence technique using anti-cytokeratin 20 (CK20) and anti-PGP 9.5. Anti-CK20 was labeled with fluorescein (green), whereas anti-PGP was labeled with rhodamine (red). a shows an oval MC accompanied by a nerve terminal-like swelling (arrows) positive for anti-PGP 9.5. b shows a dendritic MC with no contact to nerve terminal-like structure. Note that MCs show positive immunoreactions for both anti-CK20 and anti-PGP 9.5. a, b: $\times 750$

others remain at their original position and transform into DMCs.

However, if the above is indeed true, it would seem contradictory that the perilesional palatine mucosae in this study contained fewer ectopic MCs than the normal mucosa; nevertheless, they contained an abundance of DMCs. The rodent palatine epithelium, which is also rich in DMCs, seldom contained ectopic MCs (TACHibana, unpublished data). FUKUdA (1996) recently reported that the survival period of $\mathrm{MCs}$ isolated from the rat hair follicles was markedly prolonged by the addition of fetal calf serum to the culture medium and that the MCs surviving in the serum-containing media were exclusively dendritic in shape. The fetal calf serum, the inflamed human oral mucosa, and the normal rodent oral mucosa might contain common factor(s) contributing toward the mooring of denervated MCs.

A possible involvement in the mechanical reception of innervated MCs has been suggested by electrophysiological studies (for reviews see: IGGO and FINDLATER, 1984: OGAWA, 1996), though there are some objections to this view (DiAmond et al., 1986, 1988).
On the other hand, previous authors suggested that DMCs in the skin may serve to stimulate the growth or proliferation of peripheral nerves and epithelial cells, as these cells are usually present in developing fetal skin and in the bulge epithelium of adult hair follicles (Mold, R. et al., 1984, MoLl, I. et al., 1986; NARISAWA et al., 1993a, b, 1994a, b; KIM and HoLBROOK, 1995; HARTSCHUH and SCHULZ, 1995; ScHULZ and Hartschuh, 1995, 1997). However, as oral mucosa has no successively growing epithelial structures, unlike hair follicles, it seems unlikely that DMCs in the oral mucosa are involved in the proliferation of epithelial keratinocytes.

Various kinds of neuropeptides, such as met-enkephalin, VIP, and substance $\mathrm{P}$, have been localized on secretory granules of $\mathrm{MCs}$ (for reviews see: Hartschun et al, 1986; TAchibana, 1995). On the other hand, it is well known that these neuropeptides have modulatory actions on immunocytes (for reviews see: Blalock, 1989; GoETZL et al., 1990). Direct contacts between DMCs and agranular leukocytes were relatively often seen in the perilesional palatine mucosa in this study. A similar phenomenon was 


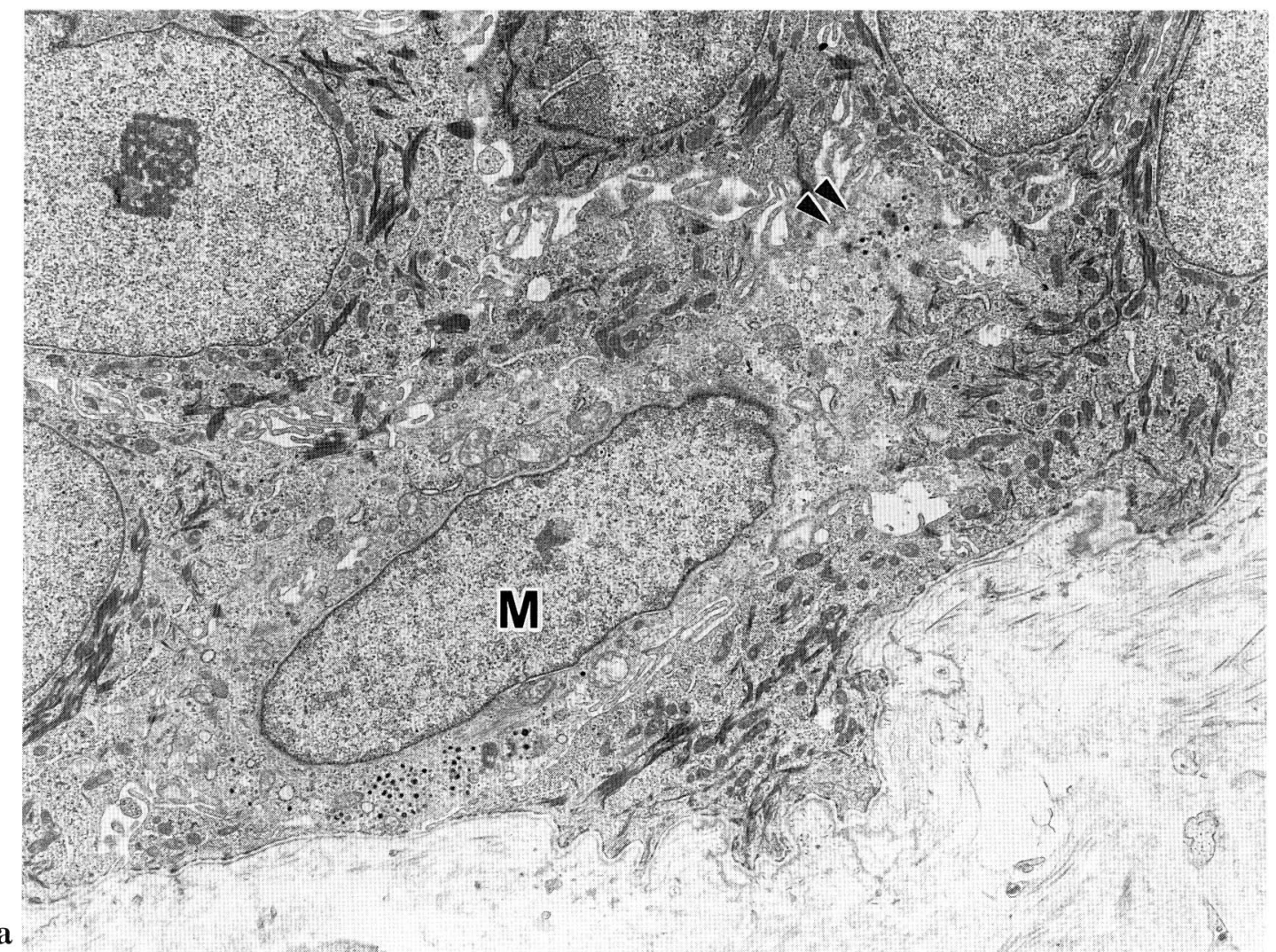

$\mathbf{a}$

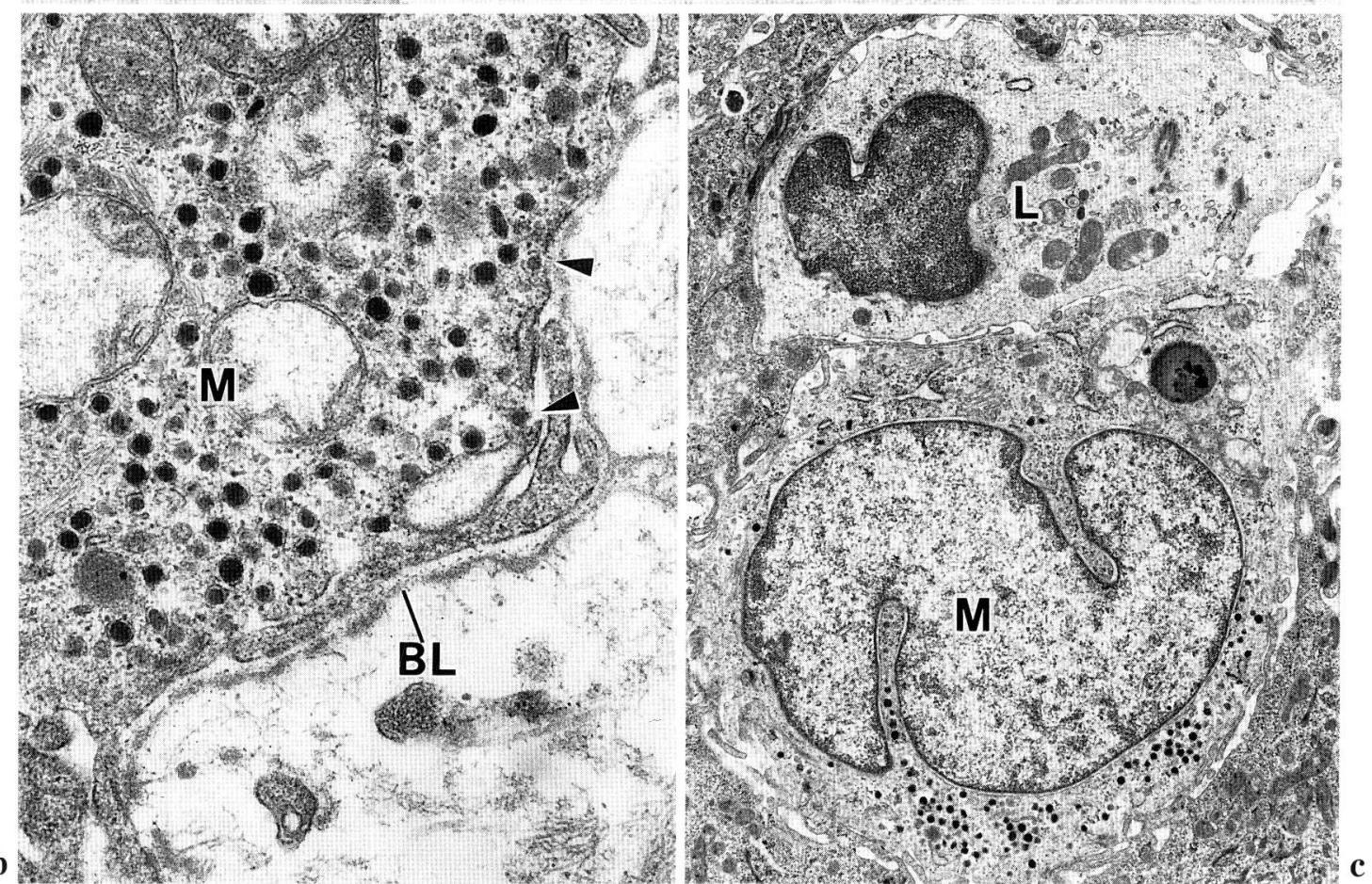

Fig. 5 a-c. Electron micrographs of dendritic Merkel cells $(M)$ in the perilesional palatine mucosa of a palatine pleomorphic adenoma (subject no. 3, in Table 2). Note that secretory granules have accumulated in the cytoplasmic process (double arrowheads) as well as in the basal cytoplasm in a and the evidence of secretory activity (arrowheads) near the basal lamina $(B L)$ in $\mathbf{b}$. $\mathbf{c}$ shows a close contact between Merkel cell $(M)$ and agranular leukocyte $(L)$. Note the accumulation of secretory granules opposite the site of the cell contact. a: $\times 6,700, \mathrm{~b}: \times 26,000, \mathrm{c}: \times 8,200$ 
shown to occasionally occur in the rodent normal palatine mucosa (TACHibANA et al., 1997). These facts imply that some regulatory interactions exist between MCs and leukocytes, though we cannot exclude a possibility of the accidental abutment of both cell types.

Perilesional palatine mucosae used in this study were very poor in innervation and only a small number of roundish MCs were innervated. This may indicate that peripheral nerve damage had occurred in the periphery of the lesions of pleomorphic adenoma and leukoplakia. If that is the case, increased DMCs in these mucosae may contribute to the regeneration of peripheral nerves through the paracrine secretion of neurotrophic factors. However, the possibility of a paracrine or endocrine function against some other targets in the lamina propria mucosae may also deserve consideration, as we have previously suggested (TACHIBANA et al., 1997).

We doubted any possibility of a change in gene expression for cytofilaments in DMCs, as the present study revealed that these cells required a higher concentration of trypsin for the unmasking of CK20antigens than other MCs. However, DMCs in the human palatine mucosa showed negative immunoreactions for these proteins. Future studies should investigate the cytokeratin patterns of DMCs.

Acknowledgments The authors thank Dr. T. YOKOBAYA. SHI of the Nagano Red Cross Hospital for his supply of materials. They also express appreciation to Dr. S. IIDA for his advice on the collection of the materials.

\section{REFERENCES}

Blalock, J. E.: A molecular basis for bidirectional communication between the immune and neuroendocrine systems. Physiol. Rev. 69: 1-32 (1989).

Diamond, J., M. Holmes and C. A. Nurse: Are Merkel cell-neurite reciprocal synapses involved in the initiation of tactile receptors in salamander skin? J. Physiol. 370: 101-120 (1986).

Diamond, J., L. R. Mills and K. M. Mearow: Evidence that the Merkel cell is not the transducer in the mechanosensory Merkel cell-neurite complex. Prog. Brain Res. 74: 51-56 (1988).

Fukuda, J.: A pure, monolayer culture of Merkel cells from sinus hair follicles of the rat. Neurosci. Lett. 216: 73-76 (1996).

Goetzl, E. J., D. C. Adelman and S. P. Sreedharan: Neuroimmunology. Adv. Immunol. 48: 161-190 (1990).

Hartschuh, W., E. Weine and M. Reinecke: The Merkel cell. In: (ed. by) A. G. J. Bereiter-Hahn, A. G. Matoltsy and K. S. Richards: Biology of the integu- ment 2. Springer-Verlag, Berlin-Heidelberg-New YorkTokyo, 1986 (p. 605-620).

Hartschun, W. and T. Schulz: Merkel cells are integral constituents of desmoplastic trichoepithelioma: an immunohistochemical and electron microscopic study. J. Cutan. Pathol. 22: 413-421 (1995).

Hillinges, M., J. Astbäck, L. Wang, K. Arvidson and O. JoHAnsson: Protein gene product 9.5immunoreactive nerves and cells in human oral mucosa. Anat. Rec. 245: 621-632 (1996).

IGGo, A. and G. S. Findlater: A review of Merkel cell mechanisms. In: (ed. by) W. HAMANN and A. IGGO: Sensory receptor mechanisms. World Scientific Publ. Co., Singapore, 1984 (p. 117-131).

KIM, D.-K. and K. A. Holbrook: The appearance, density, and distribution of Merkel cells in human embryonic and fetal skin: their relation to sweat gland and hair follicle development. J. Invest. Dermatol. 104: 411416 (1995).

Merkel, F.: 1975 Tastzellen und Tastkörperchen bei den Hausthieren und beim Menschen. Arch. Mikrosk. Anat. 11: 636-652 (1875).

Moll, I., R. Moll and W. W. Franke: Formation of epidermal and dermal Merkel cells during fetal skin development. J. Invest. Dermatol. 87: 779-787 (1986).

Moll, R., I. Moll and W. W. Franke: Identification of Merkel cells in human skin by specific cytokeratin antibodies: Changes of cell density and distribution in fetal and adult plantar epidermis. Differentiation 28: 136-154 (1984).

Moll, R., A. Löwe, J. Laufer and W. W. Franke: Cytokeratin 20 in human carcinomas. A new histodiagnostic marker detected by monoclonal antibodies. Amer. J. Pathol. 140: 427-447 (1992).

Narisawa, Y., K. Hashimoto, Y. Nakamura and $\mathbf{H}$. KoHDA: A high concentration of Merkel cells in the bulge prior to the attachment of the arrector pili muscle and the formation of the perifollicular nerve plexus in human fetal skin. Arch. Dermatol. Res. 285: 261-268 (1993a).

Narisawa, Y., K. Hashimoto and H. Kohda: Epithelial skirt and bulge of human facial vellus hair follicles and associated Merkel cell-nerve complex. Arch. Dermatol. Res. 285: 269-277 (1993b).

— - : Merkel cells of the terminal hair follicle of the adult human scalp. J. Invest. Dermatol. 102: 506-510 (1994a).

- $\longrightarrow$ : Immunohistochemical demonstration of the expression of neurofilament proteins in Merkel cell. Acta Derm. Venereol. (Stock.). 74: 441443 (1994b).

OGAW A, H.: The Merkel cell as a possible mechanoreceptor cell. Prog. Neurobiol. 49 : 317-334 (1996).

Ramieri, G., G. C. Panzica, C. Viglietti-Panzica, R. Modica, D. R. Springall and J. M. Polak: Noninnervated Merkel cells and Merkel-neurite complexes in human oral mucosa revealed using antiserum to protein gene product 9.5. Arch. Oral Biol. 37: 263-269 (1992). 
Schulz, T. and W. Hartschuh: Merkel cells in nevus sebaceus. An immunohistochemical study. Amer. J. Dermatol. 17: 570-579 (1995).

: Markel cells are absent in basal cell carcinomas but frequently found in trichoblastomas. An immunohistochemical study. J. Cutan. Pathol. 24: 14-24 (1997).

Tachibana, T.: The Merkel cell: Recent findings and unresolved problems. Arch. Histol. Cytol. 58: 379-396 (1995).

Tachibana, T., Y. Sakakura, K. Ishizeki, S. Iida and T. NAwA: Migration of Merkel cells in the labial mucous epithelium of adult rabbits following mental nerve resection. Cell Tiss. Res. 223: 659-664 (1982).

Tachibana, T., H. Yamamoto, N. Takahashi, T. Kamegai, S. Shibanai, H. Iseki and T. Nawa: Polymorphism of Merkel cells in the rodent palatine mucosa: immunohistochemical and ultrastructural studies. Arch. Histol. Cytol. 60: 379-389 (1997)
Vielkind, U., M. K. Sebzda, I. R. Gibson and M. H. HARDY: Dynamics of Merkel cell patterns in developing hair follicles in the dorsal skin of mice, demonstrated by a monoclonal antibody to mouse keratin 8 . Acta Anat. 152: 93-109 (1995).

Dr. Tamiko TACHIBAnA

Iwate Medical University School of Dentistry Chu-o-dori 1-3-27, Morioka 020-8505 Japan

立花 民子

020-8505

盛岡市中央通 1-3-27

岩手医科大学歯学部

口腔解剖学第二講座 